\title{
THERMAL STABILITY OF XYLANASES PRODUCED BY ASPERGILLUS AWAMORI
}

\author{
Judith Liliana Solórzano Lemos ${ }^{1}$; Elba P.S. Bon² ${ }^{2}$ Maria de Fátima Ebole Santana ${ }^{1}$; Nei Pereira Junior ${ }^{*}$ \\ ${ }^{1}$ Departamento de Engenharia Bioquímica, Escola de Química, Centro de Tecnologia. Universidade \\ Federal do Rio de Janeiro, Rio de Janeiro, RJ, Brasil. ${ }^{2}$ Departamento de Bioquímica, Instituto de \\ Química, Universidade Federal do Rio de Janeiro, Rio de Janeiro, RJ, Brasil
}

Submitted: September 10, 1999; Returned to authors for corrections: May 08, 2000; Approved: September 15, 2000

\begin{abstract}
The effect of temperature on the activity and stability of endoxylanase and $\beta$-xylosidase from Aspergillus awamori was investigated. The growth of A. awamori in milled sugar cane bagasse produced predominantly extracellular endoxylanase $(30 \mathrm{U} / \mathrm{ml})$ and lower amounts of $\beta$-xylosidase $(1.3 \mathrm{U} / \mathrm{ml})$. Grown in sugar cane bagasse as the principal carbon source, the microorganism produced a quite stable $\beta$-xylosidase in a temperature range of $35-55^{\circ} \mathrm{C}$, but it exhibited a lower thermostable endoxylanase. The thermostability of endoxylanase was enhanced through addition of polyhydric alcohols, mainly $2 \mathrm{M}$ xylitol and sorbitol solutions. Particular stability upon storage $(100 \%)$ was found for endoxylanase at $-4^{\circ} \mathrm{C}$ for 165 days. Yet for $\beta$-xylosidase, an activity decrease of approximately $20 \%$ was observed during the first 15 days of storage, maintaining roughly $75 \%$ of initial activity until the end of the experiment.
\end{abstract}

Key words: Aspergillus awamori; thermostability, xylanases

\section{INTRODUCTION}

Filamentous fungi have been widely studied, and the genus Aspergillus has displayed a great capacity to produce hemicellulases. Similarly to the cellulase complex, hemicellulases are seldom found in isolation but are usually present as part of a multi-component system. According to their origin, hemicelluloses are made up predominantly of heteropolymeric xylans, arabans, arabinoxylans, mannans and galactomannans. The complete degradation of hemicellulose becomes more complex than that of cellulose, since substituent-hydrolysing activities are also necessary. With heteroxylans, apart from endo-1,4- $\beta$-xylanase, which catalyses the hydrolysis of internal $\beta-1,4-x y l a n$ links (a depolymerising enzyme) and $\beta$-xylosidase, which catalyses the hydrolysis of xylooligossacharides, mainly xylobiose into xylose, other enzymes must act to accomplish the complete hydrolysis of this component. These additional enzymes are acetyl xylan esterase, $\alpha$-glucuronidase and $\alpha$-L-arabinofuranosidase, which act synergistically with endo-1,4- $\beta$-xylanase and $\beta$-xylosidase (1).

Xylanases present considerable potential in several biotechnological applications. They can be used for reducing both juice viscosity and turbidity, and for the hydrolysis of xylans into xylose to be converted biologically to single cell protein and to a whole range of fuels and chemicals $(2,3)$. Also, faced with market and legislative pressures, the pulp and paper industry is modifying its pulping, bleaching and effluent treatment technologies to reduce the environmental impact of mill effluents. Enzymatic bleaching using xylanases is one of such technologies which, in short term, offers the help to decrease substantially utilization of chlorine and its derivatives.

Stabilization of enzymes in aqueous and nonaqueous media by polyols and other substances has been widely reported. Many authors have employed these additives in different enzymatic systems (4-9). Temperature raising leads to an increase in molecules collision, as it is widely known. Beyond the critical temperature, there happens enzyme disruption and

\footnotetext{
* Corresponding author. Mailing address: Departamento de Engenharia Bioquímica, Escola de Química, Centro de Tecnologia, UFRJ, Iha do Fundão, CEP: 21949900, Rio de Janeiro, RJ, Brasil. Fax: (+5521)590-4991. E-mail: nei@eq.ufrj.br
} 
denaturation. Analogously to temperature, $\mathrm{pH}$ influences the rate of enzymatic reaction and its stability. The active site ought to be in the appropriate state of ionization to raise optimum activity (10). Within this context, the purpose of the present study was to carry out a partial characterization of endoxylanase and $\beta$-xylosidase from Aspergillus awamori, as well as the effect of some polyhydric alcohols on endoxylanase stability.

\section{MATERIALS AND METHODS}

\section{Organism and growth conditions}

Aspergillus awamori NRRL 3112 (Northern Regional Research Laboratory - Peoria, Il, USA) was maintained on sterile sand for conservation. Conidia were generated by growing the fungus on agar slants with Czapeck medium. After 5-6 day cultivation at $30^{\circ} \mathrm{C}$, conidia were scraped off and transferred to sterile distilled water. This spore suspension was used for medium inoculation in a final concentration of $10^{6}$ conidia $\mathrm{ml}^{-1}$.

\section{Media and culture conditions}

The production of enzymes was carried out in $500 \mathrm{ml}$ conical flasks, with $200 \mathrm{ml}$ culture media containing the following (g/l): peptone, 2.5; yeast extract, 2.5; $\mathrm{NaCl}, 1.0$; $\mathrm{KH}_{2} \mathrm{PO}_{4}, 1.0 ; \mathrm{MgSO}_{4} 7 \mathrm{H}_{2} \mathrm{O}, 0.2$ and dry milled bagasse, 20.0. Flasks were shaken on an orbital shaker at $170 \mathrm{rpm}$ for 5 days at $30^{\circ} \mathrm{C}$

\section{Enzymatic assays}

Endoxylanase was determined by measuring the reducing sugars from hydrolysis of birchwood xylan. $0.9 \mathrm{ml}$ solution of $1 \%$ xylan was pre-incubated in citrate phosphate buffer $50 \mathrm{mM}, \mathrm{pH} 5$, for $2 \mathrm{~min}$ at $60^{\circ} \mathrm{C}$. To this solution, $0.1 \mathrm{ml}$ of the diluted crude enzyme was added, and the reaction stopped after 2 minutes by the addition of $1 \mathrm{ml}$ of the DNS reagent. One unit of activity was defined as the amount of enzyme

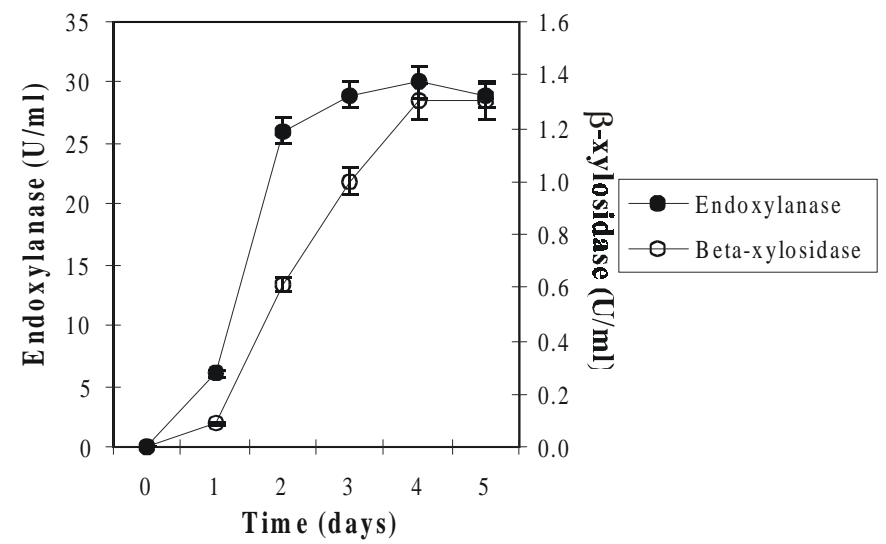

Figure 1. Production of xylanolytic enzymes at $30^{\circ} \mathrm{C}$, pH 6 and $170 \mathrm{rpm}$. required to release $1 \mu \mathrm{mol}$ of reducing sugar (xylose) per minute.

$\beta$-xylosidase activity was determined by measuring the release of $p$-nitrophenol from $p$-nitrophenyl $\beta$ xylanopiranoside (PNPX) at $410 \mathrm{~nm}$ by using a p-nitrophenol standard curve. $0.5 \mathrm{ml}$ solution of $1.25 \mathrm{mM}$ PNPX was preincubated for $2 \mathrm{~min}$ in citrate phosphate buffer $50 \mathrm{mM}$, pH 5 at $55^{\circ} \mathrm{C}$. To this solution, $0.1 \mathrm{ml}$ of the diluted crude enzyme was added, and the reaction stopped after $10 \mathrm{~min}$ by the addition of $4 \mathrm{ml}$ of $\mathrm{Na}_{2} \mathrm{CO}_{3} 0.25 \mathrm{M}$. One unit of activity was defined as the amount of enzyme required to release $1 \mu \mathrm{mol}$ of $\mathrm{p}$ nitrophenol per minute.

\section{Effect of temperature on endoxylanase and $\boldsymbol{\beta}$-xylosidase activities}

The enzymatic reactions were carried out at 30, 40, 50, 60 and $70^{\circ} \mathrm{C}$, and the enzyme activity measurements were determined as described above.

\section{Endoxylanase and $\boldsymbol{\beta}$-xylosidase stability assays}

Temperature stability was assessed by preincubating enzyme solutions at different time intervals, and at various temperatures (30-70 ${ }^{\circ} \mathrm{C}$ for endoxylanase and $35-75^{\circ} \mathrm{C}$ for $\beta$-xylosidase) prior to the addition of substrates and the determination of both endoxylanase and $\beta$-xylosidase remaining activities at $50^{\circ} \mathrm{C}$. Polyhydric alcohols: xylitol, sorbitol, mannitol and glycerol were added to the crude enzyme solution at the beginning of the preincubation, in a final concentration of 1 and $2 \mathrm{M}$. Measurements were carried out after preincubation at $50^{\circ} \mathrm{C}$ for 270 minutes, and the residual activity determined at $60^{\circ} \mathrm{C}$.

All experiments were performed in duplicates and analytical measurements in triplicates. Excel program was used to check the statistical confiability of the experimental data.

\section{RESULTS AND DISCUSSION}

Preliminary observations (Fig. 1) have demonstrated that Aspergillus awamori produces considerable levels of endoxylanase $(30 \mathrm{U} / \mathrm{ml})$ but lower levels of $\beta$-xylosidase $(1.3 \mathrm{U} / \mathrm{ml})$ when grown in milled sugar cane bagasse, and it figures as a potential microorganism for the industrial production of extracellular xylanases. Table 1 portrays extracellular xylanases production by several microorganisms. Our results show that $A$. awamori growing on an inexpensive and abundant natural substrate in Brazil was able to produce considerable levels of endoxylanase, to the same extent as Cellulomomas flavigena $(18 \mathrm{U} / \mathrm{mg})$, also inoculated on untreated sugar cane bagasse.

The effect of temperature on xylanolytic activity is shown in Fig. 2A. Endoxylanase and $\beta$-xylosidase activities were measured over a temperature range of $30-70^{\circ} \mathrm{C}$ in citrate phosphate buffer $50 \mathrm{mM}$, pH 5. Endoxylanase activity was found 

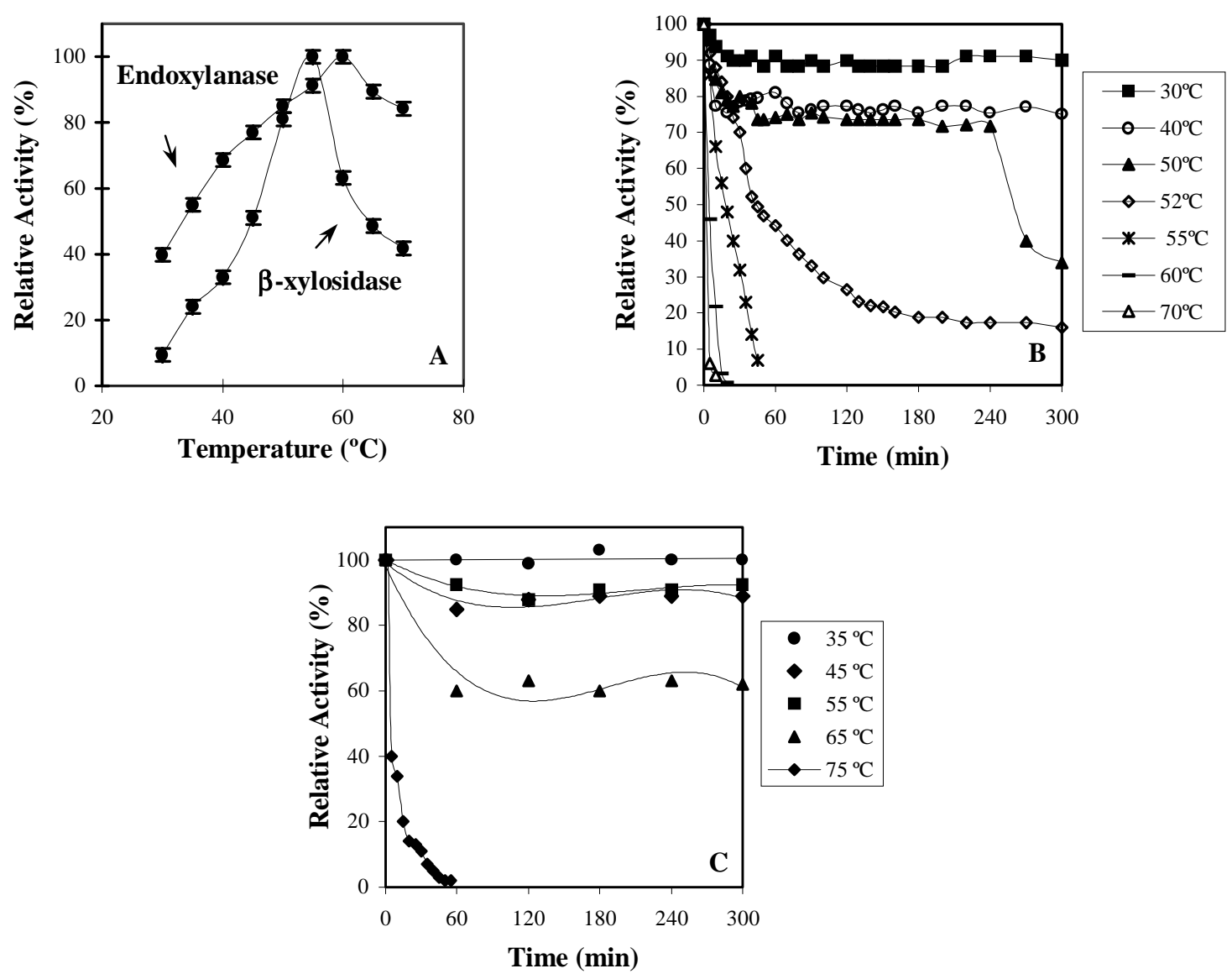

Figure 2. Effect of temperature on endoxylanase and $\beta$-xylosidase activities $(\mathbf{A})$. Thermal stability was evaluated on a crude extract solution preincubated in a range of $30-70^{\circ} \mathrm{C}$ for endoxylanase $(\mathbf{B})$, and in a range of $35-75^{\circ} \mathrm{C}$ for $\beta$-xylosidase $(\mathbf{C})$.
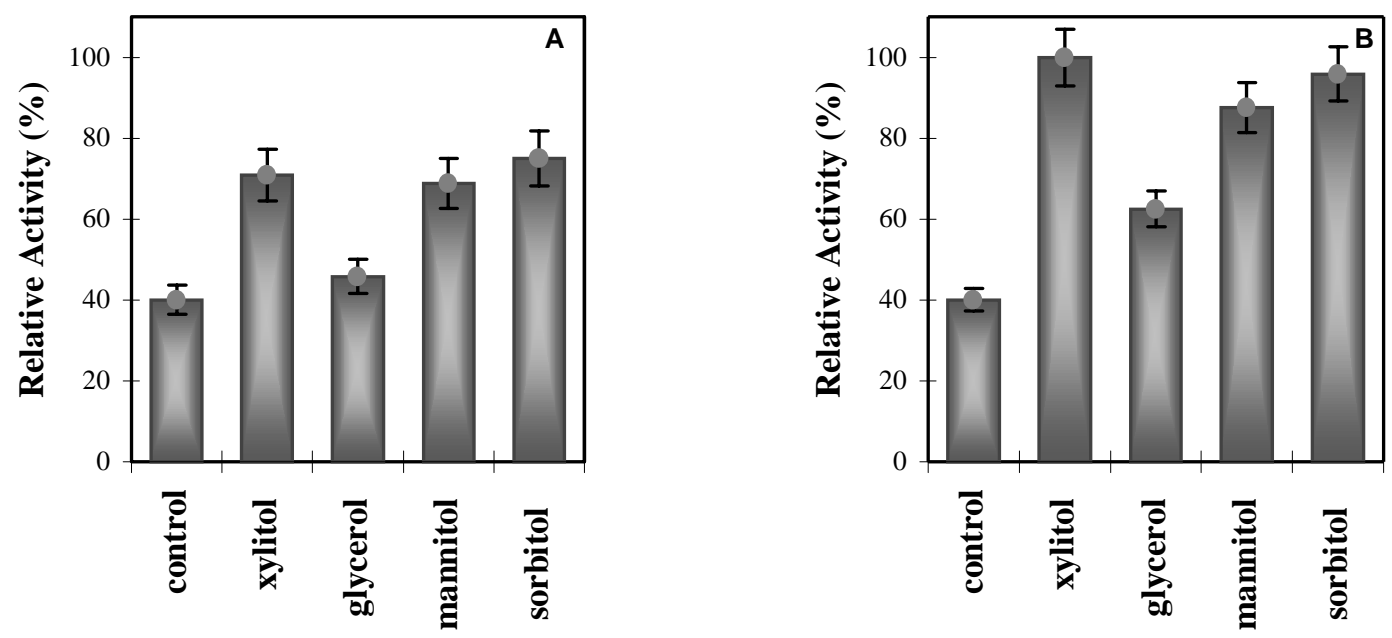

Figure 3. Effect of $1 \mathrm{M}(\mathbf{A})$ and $2 \mathrm{M}(\mathbf{B})$ polyhydric alcohols on endoxylanase stability. 
Table 1. Production of endoxylanase and $\beta$-xylosidase induced by sugar cane bagasse without previous treatment.

\begin{tabular}{|c|c|c|c|c|}
\hline Strains & $\begin{array}{c}\text { Endoxylanase Activity } \\
\left(\mathrm{Uml}^{-1}\right) \text { or } \\
\text { Specific activity }\left(\mathrm{Umg}^{-1}\right)\end{array}$ & $\beta$-xylosidase & $\begin{array}{c}\text { Fermentation } \\
\text { (time) }\end{array}$ & Reference \\
\hline Aspegillus ochraceus & $\begin{array}{l}8.5 \mathrm{Uml}^{-1} \\
18.6 \mathrm{Uml}^{-1}\end{array}$ & $\begin{array}{l}2.4 \mathrm{Uml}^{-1} \\
3.8 \mathrm{Uml}^{-1}\end{array}$ & $\begin{aligned} \text { S } & \text { (7 days) } \\
\text { SS } & \text { (16 days) }\end{aligned}$ & Biswas et al. (11) \\
\hline Aspergillus sydowii & $11.3 \mathrm{Umg}^{-1}$ & $2.2 \mathrm{Umg}^{-1}$ & S (4 days) & Gosh et al. (12) \\
\hline Aspergillus sp & $1.9 \mathrm{Uml}^{-1}$ & - & S (5 days) & Wang et al. (13) \\
\hline Aspergillus fischeri Fxn1 & $10.7 \mathrm{Uml}^{-1}$ & - & S (4 days) & Raj and Chandra (14) \\
\hline Cellulomomas flavigena & $18 \mathrm{Umg}^{-1}$ & $60.0 \mathrm{Umg}^{-1}$ & $S \quad(40 \mathrm{~h})$ & Pérez-Avalos et al. (15) \\
\hline Aspergillus tamarii & $16.7 \mathrm{Uml}^{-1}$ & $0.28 \mathrm{Uml}^{-1}$ & S (5 days) & Kadowaki et al. (16) \\
\hline Aspergillus awamori & $\begin{array}{l}30 \mathrm{Uml}^{-1} \\
18 \mathrm{Umg}^{-1}\end{array}$ & $\begin{array}{l}1.3 \mathrm{Uml}^{-1} \\
0.8 \mathrm{Umg}^{-1}\end{array}$ & S (4 days) & Present work \\
\hline
\end{tabular}

S: submerged fermentation; SS: solid state fermentation.

over a wide range of temperatures, with maximal activity at about $60^{\circ} \mathrm{C}$. Under the same conditions, $\beta$-xylosidase activity increased up to $55^{\circ} \mathrm{C}$, decreasing then dramatically at higher temperatures.

The results concerning the enzymatic stability and thermal inactivation of endoxylanase and $\beta$-xylosidase are shown in Figs. 2B and 2C, respectively. Samples were preincubated at different temperatures, and their activities measured during a long period of time. The residual activities were carried out in citrate phosphate buffer $\mathrm{pH} 5$ as indicated in the enzymatic assay procedure. Endoxylanase was reasonably stable at temperatures up to $50^{\circ} \mathrm{C}$. Yet the remaining activities decreased very rapidly when denaturation started to take place.

The maximum thermal stability was obtained at $35^{\circ} \mathrm{C}$ for $\beta$-xylosidase (Fig. 2C), and no decrease in activity was observed following incubation for at least $300 \mathrm{~min}$. However,

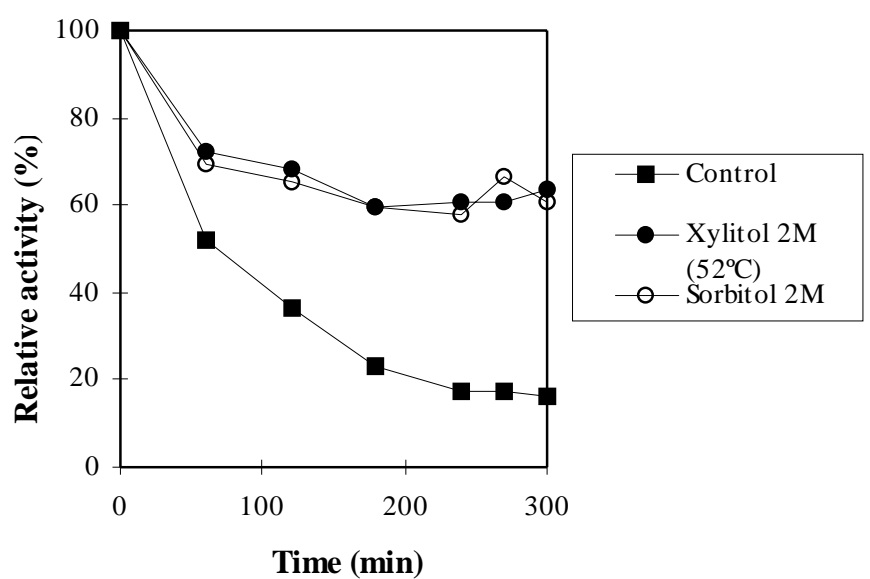

Figure 4. Time course of the protective effect of $2 \mathrm{M}$ xylitol and sorbitol on crude enzymatic solution incubated at $52^{\circ} \mathrm{C}$. on heating at 45 and $55^{\circ} \mathrm{C} \beta$-xylosidase activity decreased $c a$. $10-20 \%$, during the first hour of incubation, displaying thereafter a constant and stable activity. Under the same conditions, $\beta$-xylosidase seemed to be more stable than endoxylanase which undergoes tremendous thermal denaturation. $\beta$-xylosidases may be mono or dimeric proteins, and that one produced by A. awamori seems to be monomeric, according to Kormelink et al. (17). Hence, its thermal stability can be attributed to its intrinsic protein conformation.

Fig. 2B has shown that endoxylanase was quite stable (73\%) at least for 240 minutes at $50^{\circ} \mathrm{C}$. In order to avoid thermal inactivation, the eventual protective effect of xylitol, sorbitol, mannitol, and glycerol in aqueous medium was investigated. The results are exhibited in Fig. 3. All polyhydric alcohols had a positive effect against thermal denaturation. According to literature, the protective effect of polyols depends on the increasing number of hydroxyl groups (5). However, in the present experiment, the effect of the length of the polyhydric alcohol molecule was not clearly observed, neither when $1 \mathrm{M}$ nor $2 \mathrm{M}$ concentrations were used. Polyols raised the residual activity of the enzyme as their concentration duplicated. $2 \mathrm{M}$ xylitol as well as sorbitol exhibited the same important protective effect ( $c a .100 \%$ ) on endoxylanase after 270 minutes of preincubation. The phenomenon of protein stabilization by polyhydric alcohols may be explained by changes in the microenvironment of the enzyme, which result in a more rigid conformation of the enzyme structure. Probably, the benefit of polyols is related to the effect they promote by increasing the degree of organization of water molecules, which in turn, intensify the hydrophobic interactions among nonpolar groups. Hydrophobic interactions appear to be the single most important factor to stabilize protein structure, therefore making the protein more resistant to unfolding $(8,18,19)$. Angelo et al. (20), 


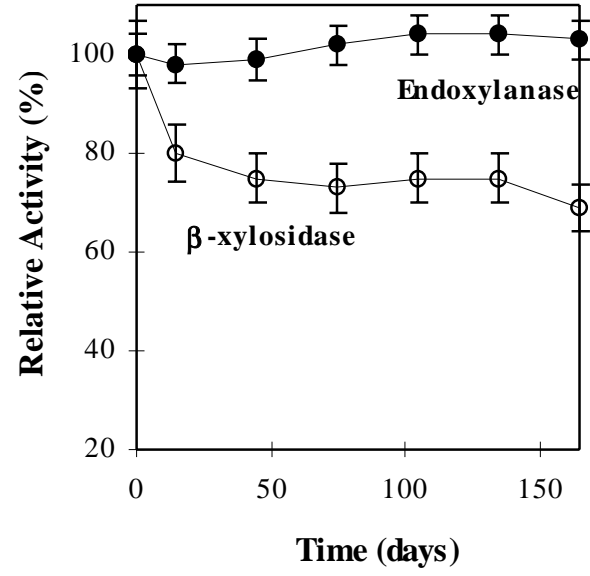

Figure 5. Effect of storage at $-4^{\circ} \mathrm{C}$ on endoxylanase and $\beta$-xylosidase activities.

studying xylanases from Aspergillus sp. found that the stability of these enzymes was markedly improved by the addition of $50 \%$ glycerol; however, in the present work this polyol contributed to the lesser extent when compared to other polyhydric alcohols.

Due to the positive results obtained with $2 \mathrm{M}$ xylitol and sorbitol solutions, their effect on a crude enzymatic extract kept at $52^{\circ} \mathrm{C}$ during $300 \mathrm{~min}$ were estimated (Fig. 4). The protective effect of both polyhydric alcohols was confirmed. Polyols are by far the best co-solvent for their ability of maintaining both solvophobic interactions essential for the native structure and the preservation of the water shell around the protein molecule (21).

Experiments were also carried out to estimate the enzyme stability concerning its storage at low temperature $\left(-4^{\circ} \mathrm{C}\right)$. The crude xylanolytic preparation was stored for 165 days, and the results are presented in Fig. 5.

A particular endoxylanase stability upon storage was found, yet for $\beta$-xylosidase a decrease was observed. The former exhibited the maximum relative activity within the whole time of assay. Nevertheless, the latter displayed a substantial decrease in activity from the first 15 days of experiment, remaining reasonably stable $(75 \%)$ onwards. Proteolysis could be responsible for the reduction of $\beta$-xylosidase activity, and endoxylanase seems to be resistant to proteolytic inactivation according to Fontes et al. (22).

\section{CONCLUSIONS}

Xylanolytic enzymes from A. awamori exhibited good stability to temperature and figure as suitable enzymes for industrial applications. $\beta$-xylosidase presented a more resistant native structure against thermal denaturation than endoxylanase, but under storage at low temperature the last one exhibited high stability. Polyols improved the endoxylanase performance, principally when $2 \mathrm{M}$ xylitol and sorbitol solutions were added to the crude enzymatic extract.

\section{RESUMO}

\section{Estabilidade térmica de xilanases produzidas por Aspergillus awamori.}

O presente trabalho trata do estudo do efeito da temperatura na atividade e estabilidade de endo-xilanase e $\beta$-xilosidase produzidas, extracelularmente, por Aspergillus awamori. $\mathrm{O}$ cultivo deste microrganismo, em bagaço de cana finamente dividido, produziu predominantemente endo-xilanases (30 U/ml) e menores atividades de $\beta$-xilosidase $(1,3 \mathrm{U} / \mathrm{ml})$; esta última exibiu considerável estabilidade em faixa de temperatura variando de 35 a $55^{\circ} \mathrm{C}$, por outro lado verificouse uma menor termo estabilidade para a endoenzima. A estabilidade térmica de endo-xilanase foi aumentada consideravelmente através da adição de polióis, principalmente xilitol e sorbitol em concentração de $2,0 \mathrm{M}$. No que concerne à estocagem a baixa temperatura $\left(-4^{\circ} \mathrm{C}\right)$, observou-se uma estabilidade particular na atividade endo-xilanásica (100\%), durante 165 dias, porém, um decréscimo de aproximadamente $20 \%$ na atividade $\beta$-xilosidásica foi verificado após os primeiros 15 dias de armazenamento nas mesmas condições, mantendo-se aproximadamente em $75 \%$ da atividade inicial no mesmo período de tempo.

Palavras-chave: Aspergillus awamori, estabilidade térmica, xilanases.

\section{REFERENCES}

1. Pereira Jr. N. Investigations of D-xylose fermenting yeast. Ph.D. Thesis. Manchester University, England, 1991.

2. Wong, K.K.Y.; Saddler, J.N. Trichoderma xylanases, their properties and application. Critical Rev. Biotechnol., 12: 413-435, 1992.

3. Sunna, A.; Antranikian, G. Xylanolitic enzymes from fungi and bacteria. Crirical Rev. Biotechnol., 17: 39-67, 1997.

4. Combes, D.; Graber, M.; Ye, W. N. Stabilizing effect of polyhydric alcohols. In: Okada, H.; Tanaka, A.; Blanch, H. (eds). Annals of the New York Academy of Science, New York, 1983, vol. 613, p. 559-563

5. Graber, M.; Combes, D. Effect of polyols on fungal alpha-amylase thermostability. Enzyme Microbiol. Technol., 11: 673-677, 1989.

6. Khmelnitsky, Y. L.; Welch, S. H.; Clark, D. S.; Dordick, J. S. Salts dramatically enhance activity of enzymes suspended in organic solvents. J. Am. Chem. Soc., 116: 2647-2648, 1994.

7. Sears, P.; Schuster, M.; Wang, P.; Witte, K.; Wong, C. Engineering subtilisin for peptide coupling: studies on the effects of counterious and site-specific modification on the stability and specificity of the enzyme. J. Am. Chem. Soc., 116: 6521-6530, 1994.

8. Triantafyllou, A. Ö.; Wehtje, E.; Adlercreutz, P.; Mattiasson, B. How do additives affect enzyme activity and stability in nonaqueous media? Biotechnol. Bioeng., 54: 67-76, 1996.

9. Rariy, R. M.; Bec, N.; Klyachko, N.; Levashov, A, V.; Balny, C. Thermobarostability of ?-chymotrypsin in reversed micelles of aerosol OT in octane solvated by water-glycerol mixtures. Biotechnol. Bioeng., 57: 552556, 1998. 
10. Coughlan, M. P. Towards an understanding of the mechanism of action of main chain-hydrolyzing xylanases. In: Visser, J.; Beldman, G.; Kusters-van Someren, M. A.; Voragen, A.G.J. (eds). Xylans and Xylanases. Elsevier Science Publishers, Amsterdam, 1992, p. 111-139.

11. Biswas, S.R., Mishra, A.K. and Nanda, G. Xylanase and ?-xylosidase production by Aspergillus ochraceus during growth on lignocelluloses. Biotechnol. Bioeng., 31: 613-616, 1988.

12. Ghosh, M., Das, A., Mishra, A.K. and Nanda, G. Aspergillus sydowii MG 49 is a strong producer of thermostable xylanolytic enzymes. Enzyme Microbiol. Technol., 15: 703-709, 1993.

13. Wang, S.L., Chen, L.G., Chen, C.S. and Chen, L.F. Cellulase and xylanase production by Aspergillus sp. G-393. Appl. Biochem. Biotechnol., 45/46: 655-662, 1994.

14. Raj, K.C. and Chandra, T.S. A cellulase-free xylanase from alkali-tolerant Aspergillus fischeri Fxn1. Biotechnol. Letters., 17: 309-314, 1995.

15. Pérez-Avalos, O., Ponce-Noyola, T., Magaña-Plaza, I. and Torre, M. Induction of xylanase and ?-xylosidase in Cellulomonas flavigena growing on different carbon sources. Appl. Microbiol. Biotechnol., 46: 405-409, 1996.
16. Kadowaki, M.K., Souza, C.G.M., Simão, R.C.G. and Peralta, R.M. Xylanase production by Aspergillus tamarii. Appl. Biochem. Biotechnol., 66: 97-106, 1997.

17. Kromelink, F. J. M.; Searle-van Leeuwen, M. F. J.; Wood, T. M. and Voragen, A. G. J. Purification and characterization of three endo-(1,4)-?-xylanase and one ?-xylosidase from Aspergillus awamori. J. Biotechnol., 27: 249-265, 1993.

18. Back, J.F.; Oakenfull, D.; Smith, M.B. Increased thermal stability of proteins in presence of sugars and polyols. Biochemistry, 18: 5191-5196, 1979.

19. Klibanov, A. M. Stabilization of enzymes against thermal inactivation. Adv. Appl. Microbiol., 29: 1-28, 1983.

20. Angelo, R.; Aguirre, C.; Curotto, E.; Esposito, E.; Fontana, J. D.; Baron, M.; Milagres A.M. F.; Durán, N. Stability and chemical modification of xylanase from Aspergillus sp. (2MI strain). Biotechnol. Appl. Biochem., 25: 19-27, 1997.

21. Gekko, K. and Timasheff, S. N. Mechanism of protein stabilization by glycerol: preferencial hydration in glycerol-water mixtures. Biochemistry, 20: 4664 4676, 1981.

22. Fontes, C. M. G. A.; Hall, J. and Hirst, B. H. The resistance of cellulases and xylanases to proteolytic inactivation. Appl. Microbiol. Biotechnol., 43: 5257, 1995. 